\title{
LOCALIZATION OF RETAIL NETWORK AND ITS CONCENTRATION IN REGIONS OF THE SLOVAK REPUBLIC
}

\author{
[Lokalizácia maloobchodnej siete a jej koncentrácia v regiónoch Slovenskej \\ republiky]
}

\author{
Rastislav Kotuličํ, Martina Marchevská ${ }^{2}$ \\ ${ }^{1}$ Fakulta manažmentu, Prešovská univerzita v Prešove, ul. 17. novembra 1, 08001 Prešov, Slovenská republika \\ Email: rastislav.kotulic@unipo.sk
}

${ }^{2}$ Fakulta manažmentu, Prešovská univerzita v Prešove, ul. 17. novembra 1, 08001 Prešov, Slovenská republika. Email: martina.spisiakova@smail.unipo.sk

\begin{abstract}
One of the most prominent features of the contemporary retail-trade in Slovakia is imminently its concentration and changing structure of the retail network where small stores and selfservice stores were replaced by large-scale business formats like supermarkets, hypermarkets and discount stores. In the scope of the retail-trade, the localization decision making is very important since a mistake in the decision and a following inconvenient location of the retail unit leads mainly to serious trade difficulties and subsequently to the crash of the store. The evaluation of the development of retail networks in regions of the Slovak Republic was realized on the basis of selected indicators of the localization and the concentration. Based on the analysis of the concentration and the localization of the retail network in regions of the Slovak Republic conducted, it can be stated that the Bratislava region demonstrates a significant dominance in the monitored period.
\end{abstract}

Keywords: retail-trade, retail network localization, localization index, localization coefficient.

JEL classification: M29, L81, R19

Doručeno redakci: 11.7.2013; Recenzováno: 9.5.2014; 11.5.2013; Schváleno k publikování: 23.9.2014

\section{Úvod}

Odvetvie maloobchodu v dôsledku transformačných zmien prešlo výraznými zmenami, ktoré ovplyvnili prevažne nákupné správanie spotrebitel’ov. Rozvoj vel'koplošných maloobchodných ret’azcov so sebou prináša mnohé pozitíva ale aj negatíva, ktoré sa priamo dotýkajú obyvatel'stva. Na jednej strane je nákupné správanie spotrebitel'ov oblúbenou činnost'ou spojenou s relaxom a trávením volných chvíl' s priatel'mi a na strane druhej množstvom nevhodne situovaných vel'koplošných jednotiek, ktoré pôsobia ako negatívne externality nie len $\mathrm{v}$ súvislosti so životným prostredím, ale aj negatívnym dopadom na životný štýl obyvatel’ov mesta bývajúcich $\mathrm{v}$ blízkosti týchto gigantov. Kolosálne múry stoja na trávnikoch, parkoch a potenciálnych detských ihriskách. Je dôležité podchytit' problematické aspekty výstavby jednotiek v súvislosti s koncentráciou a dbat' na reguláciu a plánovanie maloobchodu v SR.

Prvé vel'koplošné predajne zahraničných maloobchodných ret’azcov sa u nás začali objavovat' po rozsiahlej privatizácii a liberalizácii ekonomického prostredia niekedy v prvej polovici 90 . rokov 20. storočia. Táto prvá fáza transformácie spotrebitel'ského správania bola založená na rozvoji prvých supermarketových sietí, ktoré boli budované zväčša na zelenej lúke. (Dicken, 2003, cit. in Kunc et al., 2012)

Jedným z najvýraznejších rysov súčasného maloobchodu na Slovensku je bezprostredne jeho koncentrácia a meniaca sa štruktúra maloobchodnej siete, kedy malé predajne a samoobsluhy boli nahradené vel'koplošnými obchodnými formátmi ako sú supermarkety, hypermarkety 
a diskonty. Výstavba týchto vel'koplošných zariadení však priniesla i obmedzenia. Tu sa dostávajú $\mathrm{k}$ slovu lokalizačné modely, analýzy a rôzne teórie týkajúce sa priestorového chovania nakupujúcich, verejnej vybavenosti a uspokojovania potrieb vôbec. (Spilková, 2012)

\section{Teoretické východiská}

Maloobchod je možné chápat' ako súhrn všetkých činností, ktoré bezprostredne súvisia s predajom výrobkov alebo poskytovaním služieb konečným spotrebitel'om. (Mitríková, 2008) Maloobchod je v zásade možné chápat' aj ako decentralizovaný predaj spotrebného tovaru vo väčšom počte dislokovaných obchodných prevádzok. Za primárnych odberatel'ov sa považujú domácnosti a jednotlivci. (Bartáková et al., 2007) Štatistický úrad Slovenskej republiky pod ojem maloobchod zahŕňa predaj nového a použitého tovaru pre osobnú potrebu alebo použitie $\mathrm{v}$ domácnosti. Do maloobchodného predaja sa tiež zarad’uje predaj písacích strojov, papierenského tovaru, farieb alebo dreva, i ked' tieto výrobky nemusia byt' len pre osobnú spotrebu alebo pre použitie $\mathrm{v}$ domácnosti. Do maloobchodného predaja bežne nevstupuje predaj obilnín, rúd, nafty, priemyselných chemikálií, železa, ocele a priemyselných strojov a zariadení. Do tohto oddielu sú tiež zahrnuté opravy tovaru osobnej spotreby a potrieb pre domácnost'. V rámci priestorového usporiadania maloobchodnej siete platia tri základné princípy jeho formovania: (1) relatívna rovnomernost' a koncentrácia maloobchodnej siete, kde ide o rovnováhu medzi potenciálom kúpyschopnosti obyvatel'stva a kapacitami maloobchodnej siete, (2) hierarchia maloobchodnej vybavenosti, ktorá predstavuje hierarchiu frekvencie uspokojovania potrieb obyvatel'stva tovarom dennej spotreby a (3) komplexnost' maloobchodnej vybavenosti, ktorá úzko súvisí so stupňami vybavenosti (okrsková, obvodová, štvrt’ová, centrálna vybavenost') t. j. vyššia úroveň vybavenosti by mala uspokojovat' tiež dopyt $v$ rozsahu nižšieho stupňa vybavenosti. (Mitríková, 2008)

Koncentrácia vo všeobecnosti znamená sústredenie obchodných činností, podnikov okolo jedného centra. Z geografického hl'adiska možno koncentráciu poňat' ako schopnost' podnikov sústred'ovat' sa a d'alej rozvíjat' na miestach, kde sa nachádzajú aj iné podniky. Úroveň koncentrácie je možné vyjadrit' z pohl'adu: (1) koncentrácie výroby, ktorá sa vyjadruje prostredníctvom ukazovatel'a podiel podnikov na celkovom objeme vyrábanej produkcie, (2) koncentrácia obyvatel'stva, ktorú možno vyjadrit' ako percento urbanizácie krajiny a podielom vel'kých miest, (3) koncentrácie obchodných podnikov vyjadrujúce cez zväčšsvanie plošnej vel'kosti podnikov, zvyšovaním podielu vel'koplošných maloobchodných jednotiek na maloobchodnom obrate a zvyšovaním podielu podnikov na obrate. (Viestová, 1995)

Koncentráciu maloobchodnej siete v regióne je možné vyjadrit' aj prostredníctvom vybraných indikátorov ako napr.: obslužný štandard, ktorý vyjadruje počet obyvatel'ov sledovaného regiónu pripadajúcich na jedného pracovníka v maloobchode; plošný štandard, ktorý vyjadruje počet obyvatel'ov sledovaného regiónu pripadajúcich na jedného pracovníka v maloobchode; hustota maloobchodnej siete, ktorá vyjadruje počet podnikov pripadajúcich na $100 \mathrm{~km}^{2}$ sledovaného regiónu; využitel’nost' predajnej plochy, ktorá predstavuje objem tržieb, ktoré sú vyprodukované na $\mathrm{m}^{2}$ predajnej plochy; produktivita práce, ktorá vyjadruje tržby za kalendárny rok pripadajúce na jedného pracovníka maloobchodu. (Spilková, 2012)

$\mathrm{V}$ rámci maloobchodu je lokalizačné rozhodovanie vel'mi dôležité, pretože chyba v rozhodovaní a následné nevhodné umiestnenie maloobchodnej jednotky vedie prevažne k závažným obchodným problémom a následne ku krachu predajne. Obchodníci, či obchodné ret’azce sa rozhodujú na základe tržného potenciálu v mieste, logistických väzieb, dopravných podmienok, ako aj podl'a lokalizačných krokov svojich konkurentov. Niektoré ret'azce 
uprednostňujú umiestnenie svojich prevádzok blízko svojich konkurentov s podobným produktovým mixom, iní sa snažia vstúpit' na trh ako prvý a tak využit' moment prekvapenia, než sa do plánovaného okolia dostanú iní konkurenti. Často sa stáva, že sú predajne lokalizované do miest, kde sa plánujú dynamické zmeny a nárast tržného potenciálu, napr. výstavba bytových jednotiek. (Spilková, 2012) Lokalizácia je proces výberu miesta (regiónu) pre konkrétnu socioekonomickú aktivitu. Každý región disponuje určitými zdrojmi a každá aktivita sa vyznačuje istými potrebami. Najlepšie umiestnenie prevádzky je tam, kde sú optimálne zdroje pre dané socioekonomické aktivity. Preto je možné stotožnit'sa s názorom, že lokalizácia je najdôležitejšia téma skúmania so zameraním na využitie priestoru. (Ježek et al., 2007)

Osídlenie obyvatel'stva je do značnej miery ovplyvňované lokalizačnými tendenciami v diverzifikácií podnikatel'ských aktivít. Expanzia maloobchodných predajni v osídlení zvyšuje schopnost' absorbovat' väčšie prevádzkové kapacity, ktoré prinášajú so sebou aj ekonomické výhody: pri rastúcej prevádzkovej kapacite sa rozširujú možnosti väčšieho predaja sortimentu, možnosti del’by práce formou špecializácie, ako aj lepšia organizácia plynulosti obsluhy; zvýšeným predajom sortimentu sa znižujú investičné a prevádzkové náklady na jednotku výroby; väčšie maloobchodné jednotky majú úspešnejšie predpoklady pre vlastný technický rozvoj. (Buček et al., 1992)

Medzi lokalizačné faktory, ktoré ovplyvňujú rozhodovanie umiestnenia investícií patria: obchodné faktory - blízkost' trhu a zákazníkov, dostupnost' zdrojov, prítomnost' podobných firiem; národné a lokálne faktory - jazykové schopnosti, podpora verejnej správy, úroveň zdanení, ponuka rozvojových plôch; infraštrukturálne faktory - kvalita dial'nic a železníc, telekomunikácií, blízkost' vel'kých letísk a prístavov; pracovné faktory - kvalita a dostupnost' pracovných síl, flexibilita pracovných síl; nákladové faktory - cena práce, pozemkov, prenájmu; kultúrne a environmentálne faktory. (Hofman et al., 2005) Za klasické tvrdé lokalizačné faktory Thießen (2005, cit. in Slach, 2008) považuje: cenu plôch, dostupnost' kapitálu a dobre vyškolené pracovné sily. Tie sa stávajú stále viac všadeprítomné a relatívne strácajú na svojom tradičnom význame pre priestorovú alokáciu firiem a mobilitu pracovných síl. Tvrdé lokalizačné faktory sú také faktory, ktorých kvalita a úroveň je primárne kalkulovaná ako napr.: disponibilita kvalifikovanými l'udskými zdrojmi, dopravné spojenie, ceny za plochy, priestory a budovy, kapitál a pod. Pre vysoko kvalifikované pracovné sily a firmy nadobúdajú na relevantnom význame tzv. mäkké lokalizačné faktory: (1) mäkké podnikatel'ské lokalizačné faktory, ktoré majú bezprostredný vplyv na aktivitu podnikov/podnikatel'ov, avšak nie sú primárne kalkulovatel'né či meratel'né. Sú predmetom subjektívneho hodnotenia každého podnikatel'a/podniku, napr. image, kultúra, identita, ústretovost' verejného sektoru a pod.; (2) mäkké individuálne lokalizačné faktory, ktoré sú záležitost’ou osobných preferencií pracovníkov manažmentu, ako aj samotných zamestnancov a nemajú bezprostredný vplyv na aktivity podnikov. Vplyv majú predovšetkým na ich pracovnú motiváciu a pracovnú efektivitu, respektíve celkovou disponibilitu vysoko kvalifikovanými l’udskými zdroji v regióne. (Slach, 2008)

Ak berieme do úvahy nadnárodné spoločnosti, tak tie využívajú výhody lokalizačných faktorov $\mathrm{v}$ rôznych častiach sveta a tak produkcia tovarov a služieb je organizovaná na nadnárodnej úrovni. Hlavným ciel'om využitia lokalizačných faktorov je maximalizácia zisku a akumulácia kapitálu. V prípade, že skúmaný trh je nasýtený a neponúka mnoho možností pre d'alší rast, dochádza ku expanzii na nové trhy. (Skopal et al., 2008). 


\section{Popis dát a použitých metód}

Ciel'om príspevku je zhodnotit' postavenie maloobchodnej siete $\mathrm{v}$ regiónoch na úrovni NUTS III (na úrovni krajov) Slovenskej republiky pomocou vybraných indikátorov koncentrácie a lokalizácie. Predpokladáme, že s pomocou vybraných indikátorov koncentrácie a lokalizácie prispejeme k čiastočnému objasneniu expanzie a postaveniu maloobchodnej siete v regiónoch Slovenskej republiky. Prevažná čast' empirických štúdií zmienená v úvode a v teoretickom prehlade sa metodicky opiera o zdroj primárnych informácii získaných prostredníctvom dotazníkového prieskumu. Pre účely nášho výskumu boli využité sekundárne informácie, ktoré sme získali z oficiálne dostupných zdrojov Štatistického úradu Slovenskej republiky za sledované obdobie rokov 2001 - 2010. Pri hodnotiacom procese boli využité štandardné matematicko-štatistické vzt'ahy a numerické výpočty.

Meranie koncentrácie maloobchodnej siete na Slovensku bolo vyjadrené prostredníctvom nasledujúcich ukazovatel'ov:

- obslužný štandard (OŠ), ktorý vyjadruje počet obyvatel'ov pripadajúcich na 1 pracovníka v sieti maloobchodu v podnikoch s 20 a viac zamestnancami,

$$
O \check{S}=\frac{E_{i j}}{S_{j}}
$$

kde $\mathrm{E}_{\mathrm{ij}} \quad=$ počet zamestnaných i-odvetvia $\mathrm{v}$ j-tom regióne,

$\mathrm{S}_{\mathrm{j}} \quad=$ počet obyvatel'ov j-regiónu,

- plošný štandard (PŠ), ktorý vyjadruje vel'kost' predajnej plochy $\mathrm{v}^{2}$ pripadajúcu na 1000 obyvatel'ov,

$$
P \check{S}=\frac{P P_{i j}}{S_{j}} \cdot 1000
$$

kde $\mathrm{PP}_{\mathrm{ij}}=$ vel'kost' predajnej plochy $\mathrm{v} \mathrm{m}^{2} \mathrm{i}$-odvetvia $\mathrm{v} \mathrm{j}$-tom regióne,

$\mathrm{S}_{\mathrm{j}} \quad=$ počet obyvatel'ov j-regiónu.

- využitel’nost’ predanej plochy (VPP), ktorá predstavuje objem tržieb pripadajúcich na jeden $\mathrm{m}^{2}$ predajnej plochy,

$$
V P P=\frac{T r z ̌ b y_{i j}}{P P_{i j}}
$$

kde Tržby $_{\mathrm{ij}} \quad=$ tržby $\mathrm{v}$ eurách i-odvetvia $\mathrm{v}$ j-tom regióne,

$\mathrm{PP}_{\mathrm{ij}} \quad=$ vel'kost' predajnej plochy $\mathrm{v} \mathrm{m}^{2} \mathrm{i}$-odvetvia $\mathrm{v}$ j-tom regióne.

V rámci hodnotenia priestorových súvislostí maloobchodu bol použitý ukazovatel' index lokalizácie (IL). (Michaeli et al., 2009) Index lokalizácie, meria pomer zastúpenia sledovaného odvetvia $v$ regiónoch $\mathrm{k}$ počtu obyvatel'ov. (Tej, 2007) Index lokalizácie vyjadruje vzt'ah:

$$
\begin{aligned}
& I L= \frac{\frac{E i j}{E i}}{\frac{S j}{S}} \\
& \mathrm{kde} \quad \mathrm{E}_{\mathrm{ij}} \quad=\text { počet zamestnaných i-odvetvia } \mathrm{v} \text { j-tom regióne, } \\
& \mathrm{E}_{\mathrm{i}} \quad=\text { počet zamestnaných i-odvetvia v krajine, } \\
& \mathrm{S}_{\mathrm{j}} \quad=\text { počet obyvatel'ov j-regiónu, } \\
& \mathrm{S} \quad=\text { počet obyvatel'ov v krajine. }
\end{aligned}
$$


Pre hodnoty indexu lokalizácie platia nasledujúce vzt'ahy: IL $<1$ odvetvie maloobchodu je k počtu obyvatel'ov zastúpené podproporcionálne; IL $=1$ odvetvie maloobchodu je k počtu obyvatel'ov zastúpené proporcionálne; IL $>1$ odvetvie maloobchodu je vzhl'adom k počtu obyvatel'ov zastúpené nadproporcionálne.

Z dôvodu nedostupnosti a nezrovnalostí niektorých informačných zdrojov bolo upustené od niektorých analýz a komparácií. Najmä preto aj niektoré výsledky môžu mat' čiastkovú platnost' pre hodnotiacu analýzu. V budúcom výskume autori zvažujú analýzu rozšírit' aj o iné kritéria s ciel'om viac objektivizovat' získané výsledky

\section{Analýza koncentrácie a lokalizácie maloobchodnej siete v regiónoch Slovenska}

Ukazovatel' obslužný štandard vyjadruje počet obyvatel'ov pripadajúcich na jedného pracovníka maloobchodu a čím je jeho hodnota nižšia, tým je koncentrácia maloobchodu vyššia. Pri analýze ukazovatel'a obslužný štandard (tabul'ka č.1) je vidiet' významné rozdiely medzi Bratislavským krajom a zvyškom Slovenska, kde hodnoty pre Bratislavský kraj sú výrazne lepšie voči všetkým ostatným krajom (v priemere je to 6,25 krát viac v roku 2001 a 7,86 krát viac v roku 2010).

Tabul'ka 1: Obslužný štandard za jednotlivé kraje Slovenska

\begin{tabular}{|c|c|c|c|c|c|c|c|c|c|}
\hline ROK / KRAJ & & BA & TT & TN & NR & $\mathbf{Z A}$ & BB & PO & KE \\
\hline \multirow[b]{2}{*}{2001} & OŠ & 34,7 & 210,2 & 140,8 & 238,6 & 158,3 & 162,5 & 268,2 & 325,8 \\
\hline & $\begin{array}{l}\text { Pomer } \\
\text { (kraj / najlepší kraj) }\end{array}$ & 1,00 & 6,06 & 4,06 & 6,88 & 4,56 & 4,68 & 7,73 & 9,39 \\
\hline \multirow{3}{*}{2002} & OŠ & 29,3 & 184,9 & 129,1 & 208,9 & 153,8 & 153,0 & 240,6 & 336,3 \\
\hline & Tempo prírastku \% & 15,56 & 12,04 & 8,31 & 12,45 & 2,84 & 5,85 & 10,29 & $-3,22$ \\
\hline & $\begin{array}{l}\text { Pomer } \\
\text { (kraj / najlepší kraj) }\end{array}$ & 1,00 & 6,31 & 4,41 & 7,13 & 5,25 & 5,22 & 8,21 & 11,48 \\
\hline \multirow{3}{*}{2003} & OŠ & 28,5 & 176,1 & 132,3 & 199 & 156,3 & 145,3 & 242,2 & 342,1 \\
\hline & Tempo prírastku \% & 2,73 & 4,76 & $-2,48$ & 4,74 & $-1,63$ & 5,03 & $-0,67$ & $-1,72$ \\
\hline & $\begin{array}{l}\text { Pomer } \\
\text { (kraj / najlepší kraj) }\end{array}$ & 1,00 & 6,18 & 4,64 & 6,98 & 5,48 & 5,10 & 8,50 & 12,00 \\
\hline \multirow{3}{*}{2004} & OŠ & 26,1 & 173,7 & 137,2 & 205,5 & 155,9 & 159,5 & 238,5 & 304,8 \\
\hline & Tempo prírastku \% & 8,42 & 1,36 & $-3,70$ & $-3,27$ & 0,26 & $-9,77$ & 1,53 & 10,90 \\
\hline & $\begin{array}{l}\text { Pomer } \\
\text { (kraj / najlepší kraj) }\end{array}$ & 1,00 & 6,66 & 5,26 & 7,87 & 5,97 & 6,11 & 9,14 & 11,68 \\
\hline \multirow{3}{*}{2005} & OS & 24,6 & 179,1 & 124,0 & 200,6 & 139,2 & 139,6 & 237,3 & 387,5 \\
\hline & Tempo prírastku \% & 5,75 & $-3,11$ & 9,62 & 2,38 & 10,71 & 12,48 & 0,50 & $-27,13$ \\
\hline & $\begin{array}{l}\text { Pomer } \\
\text { (kraj / najlepší kraj) }\end{array}$ & 1,00 & 7,28 & 5,04 & 8,15 & 5,66 & 5,67 & 9,65 & 15,75 \\
\hline \multirow{3}{*}{2006} & OŠ & 22,7 & 169,1 & 140,3 & 194,2 & 129,1 & 124,6 & 236,8 & 389,5 \\
\hline & Tempo prírastku \% & 7,72 & 5,58 & $-13,15$ & 3,19 & 7,26 & 10,74 & 0,21 & $-0,52$ \\
\hline & $\begin{array}{l}\text { Pomer } \\
\text { (kraj / najlepší kraj) }\end{array}$ & 1,00 & 7,45 & 6,18 & 8,56 & 5,69 & $5 ., 49$ & 10,43 & 17,16 \\
\hline \multirow{3}{*}{2007} & OŠ & 22,1 & 158,5 & 103,4 & 194,2 & 116,2 & 121,2 & 215,2 & 307,9 \\
\hline & Tempo prírastku \% & 2,64 & 6,27 & 26,3 & 0,00 & 9,99 & 2,73 & 9,12 & 20,95 \\
\hline & $\begin{array}{l}\text { Pomer } \\
\text { (kraj / najlepší kraj) }\end{array}$ & 1,00 & 7,17 & 4,68 & 8,79 & 5,26 & 5,48 & 9,74 & 13,93 \\
\hline \multirow{3}{*}{2008} & OŠ & 20,7 & 145,3 & 111,0 & 200,2 & 108,3 & 111,1 & 181,1 & 232,5 \\
\hline & Tempo prírastku \% & 6,33 & 0,08 & $-0,07$ & $-0,03$ & 0,07 & 0,08 & 0,16 & 0,24 \\
\hline & $\begin{array}{l}\text { Pomer } \\
\text { (kraj / najlepší kraj) }\end{array}$ & 1,00 & 7,02 & 5,36 & 9,67 & 5,23 & 5,37 & 8,75 & 11,23 \\
\hline \multirow{3}{*}{2009} & OS & 20 & 135,7 & 116,7 & 189,6 & 112,6 & 106,9 & 166,2 & 256,2 \\
\hline & Tempo prírastku \% & 3,38 & 6,61 & $-5,14$ & 5,29 & $-3,97$ & 3,78 & 8,23 & $-10,19$ \\
\hline & $\begin{array}{l}\text { Pomer } \\
\text { (kraj / najlepší kraj) }\end{array}$ & 1,00 & 6,79 & 5,84 & 9,48 & 5,63 & 5,34 & 8,31 & 12,81 \\
\hline \multirow{4}{*}{2010} & OŠ & 19,5 & 128,2 & 123,1 & 187 & 120 & 108,6 & 173,7 & 238,5 \\
\hline & Tempo prírastku \% & 2,50 & 5,53 & 5,48 & 1,37 & $-6,57$ & $-1,59$ & $-4,51$ & 6,91 \\
\hline & $\begin{array}{l}\text { Pomer } \\
\text { (kraj / najlepší kraj) }\end{array}$ & 1,00 & 6,57 & 6,31 & 9,59 & 6,15 & 5,57 & 8,91 & 12,23 \\
\hline & $\begin{array}{l}\text { Tempo prírastku \% (za } \\
10 \text { rokov) }\end{array}$ & 43,8 & 39,0 & 12,5 & 21,6 & 24,1 & 33,1 & 35,2 & 26,8 \\
\hline
\end{tabular}

Vysvetlivky: OŚ - obslužný štandard; BA - Bratislavský kraj, TT - Trnavský kraj, TN - Trenčiansky kraj, NR Nitriansky kraj, ZA - Žilinský kraj, BB - Banskobystrický kraj, PO - Prešovský kraj, KE - Košický kraj Zdroj: ŠÚ SR, vlastné spracovanie 
Najhoršie na tom boli v roku 2001 kraje Košický a Prešovský, teda kraje tvoriace východnú čast' Slovenska a za nimi nasledoval Nitriansky kraj. Tieto 3 územné jednotky boli na tom percentuálne 7 až 9,5 krát horšie ako samotný Bratislavský kraj. Zvyšné 4 územné jednotky zaostávali za Bratislavským krajom 4 až 6 násobne. V roku 2002 pozorujeme rast koncentrácie u všetkých krajov, pričom najvýraznejšie je to badat' u Bratislavského kraja (15,56 \%). Rok 2003 sa javil ako rok stagnácie pre všetky kraje. Z tabul'ky č. 1 je d'alej možné pozorovat' aj to, že len zriedkakedy sa niektorému kraju podarilo prekročit' medziročný rast koncentrácie meranej prostredníctvom ukazovatel'a obslužný štandard viac ako o $10 \%$. Výraznejšie sa túto hranicu podarilo prekročit' len Trenčianskemu kraju (rok 2007 s rastom 26,30 \%) a Košickému kraju (rok 2007 s rastom 20,95 \%).

V sledovanom období ani jeden kraj nedokázal udržat' tempo rastu koncentrácie meranej prostredníctvom ukazovatel'a obslužný štandard voči Bratislavskému kraju. Najvýraznejšie zmeny v absolútnom vyjadrení zaznamenal Prešovský, Košický a Nitriansky kraj. Najvýraznejšie zmeny v relatívnom vyjadrení zaznamenal Bratislavský kraj s 43,80 \% rastom koncentrácie. Najviac sa $\mathrm{v}$ tempe rastu koncentrácie meranej prostredníctvom ukazovatel'a obslužný štandard priblížil k Bratislavskému kraju Trnavský kraj (39,01 \%) a Prešovský kraj $(35,23 \%)$. Z analýzy obslužného štandardu sa dá usudzovat' prehlbovanie regionálnych rozdielov v rámci maloobchodnej siete, čo sa prejavuje divergenciou v rámci koncentrácie meranej prostredníctvom ukazovatel'a obslužný štandard voči najlepšie umiestnenému Bratislavskému kraju.

Ukazovatel' plošný štandard vyjadruje vel'kost' predajnej plochy, ktorá pripadá na tisíc obyvatel'ov sledovaného kraja a čím je jeho hodnota väčšia, tým je koncentrácia maloobchodnej siete vyššia a jeho vybavenost' lepšia. Pri analýze ukazovatel'a plošný štandard (tabul'ka č.2) je možné sledovat' to, že v roku 2001 sa iba Bratislavský kraj ako jediný približoval k hodnote $1 \mathrm{~m}^{2}$ na obyvatel'a. Ostatných 7 krajov nedokázalo prekročit' ani hranicu $0,2 \mathrm{~m}^{2}$ na obyvatel'a. Druhým najlepším bol Trenčiansky kraj s $0,173 \mathrm{~m}^{2}$ na obyvatel'a a najhoršie na tom boli kraje východného Slovenska: Košický a Prešovský kraj, ktoré nedokázali prekročit' hranicu $0,1 \mathrm{~m}^{2}$ na obyvatel'a. Ešte výraznejšie sú tieto zmeny viditel'né v relatívnom meradle, v ktorom bol Prešovský kraj na úrovni $10 \%$ hodnôt Bratislavského kraja a Košický kraj na úrovni 8 \% hodnôt Bratislavského kraja.

Údaje za rok 2002 tiež vykazujú obrovský nárast plochy na obyvatel'a (až $63 \%$ ) v najvýraznejšej z týchto územných jednotiek (Bratislavský kraj), zatial’ čo z ostatných územných jednotiek vykázal výraznejšiu percentuálnu zmenu len Prešovský kraj (41\%), čím sa mu podarilo prekročit' hodnotu $0,1 \mathrm{~m}^{2}$ predajnej plochy na obyvatel'a. Výraznú zmenu pozorujeme v Banskobystrickom kraji v roku 2004 a to takmer rast o $250 \%$ voči predchádzajúcemu roku. V nasledujúcom období pre daný kraj je možné pozorovat' prepad o vyše $60 \%$. V roku 2006 sa prejavil potenciál Žilinského kraja, kde je možné pozorovat' nárast o $150 \%$.

V priebehu sledovaného obdobia desiatich rokov je možné konštatovat', že ani jeden zo sledovaných krajov nedokázal napodobnit' progres Bratislavského kraja v tomto meradle, zabezpečený síce menej výraznými, ale za to pravidelnými prírastkami na úrovni takmer $10 \%$ v každom roku. Z daného vývoja je možné vidiet' aj to, že všetky kraje ostali hlboko pod úrovňou $0,5 \mathrm{~m}^{2}$ plochy na obyvatel'a. Košický kraj dokonca nedokázal prekročit' hranicu 0,15 $\mathrm{m}^{2}$ plochy na obyvatel'a. Najlepšie výsledky dosahoval Bratislavský kraj, ktorý sa dostal na hranicu $2,44 \mathrm{~m}^{2}$ plochy na obyvatel'a, čo v relatívnom vyjadrení znamená nárast koncentrácie maloobchodnej siete meranej ukazovatel'om plošný štandard $\mathrm{v}$ sledovanom 
období desiatich rokov viac než o 200 \%. Druhý najlepší rast v sledovanom období desiatich rokov dosiahol Prešovský kraj (takmer o $170 \%$ ) a na tret'om mieste sa umiestnil Banskobystrický kraj (s rastom $153 \%$ ). Z analýzy plošného štandardu sa dá pozorovat' prehlbovanie regionálnych rozdielov v rámci maloobchodnej siete a výraznú divergenciu voči najlepšie umiestnenému Bratislavskému kraju.

Tabul'ka 2: Plošný štandard za jednotlivé kraje Slovenska

\begin{tabular}{|c|c|c|c|c|c|c|c|c|c|}
\hline ROK / KRAJ & & BA & TT & $\mathbf{T N}$ & NR & $\mathbf{Z A}$ & BB & PO & $\mathbf{K E}$ \\
\hline \multirow[b]{2}{*}{2001} & PŠ & 807,7 & 124,3 & 173,4 & 114,6 & 136 & 107,9 & 82,1 & 67,5 \\
\hline & \begin{tabular}{|l} 
Pomer \\
(kraj / najlepší kraj)
\end{tabular} & 1 & 0,2 & 0,2 & 0,1 & 0,2 & 0,1 & 0,1 & 0,1 \\
\hline \multirow{3}{*}{2002} & PŠ & 1314,2 & 124,8 & 185,7 & 129 & 157 & 116,8 & 115,8 & 67,7 \\
\hline & \begin{tabular}{|l|} 
Tempo prírastku \% \\
\end{tabular} & 62,7 & 0,4 & 7,1 & 12,6 & 15,4 & 8,2 & 41 & 0,3 \\
\hline & \begin{tabular}{|l} 
Pomer \\
(kraj / najlepší kraj)
\end{tabular} & 1 & 0,1 & 0,1 & 0,1 & 0,1 & 0,1 & 0,1 & 0,1 \\
\hline \multirow{3}{*}{2003} & PŠ & 1499,4 & 126,7 & 186,5 & 128,9 & 151,6 & 117,8 & 102,8 & 66,8 \\
\hline & Tempo prírastku \% & 14,1 & 1,5 & 0,4 & $-0,1$ & $-3,4$ & 0,9 & $-11,2$ & $-1,3$ \\
\hline & \begin{tabular}{|l} 
Pomer \\
(kraj / najlepší kraj)
\end{tabular} & 1 & 0,1 & 0,1 & 0,1 & 0,1 & 0,1 & 0,1 & 0 \\
\hline \multirow{3}{*}{2004} & PŠ & 1581,7 & 129,3 & 269 & 134 & 170,5 & 410,3 & 100,8 & 81,1 \\
\hline & Tempo prírastku \% & 5,5 & 9,9 & 44,2 & 4 & 12,5 & 248,3 & $-1,9$ & 21,4 \\
\hline & $\begin{array}{l}\text { Pomer } \\
\text { (kraj / najlepší kraj) }\end{array}$ & 1 & 0,1 & 0,2 & 0,1 & 0,1 & 0,3 & 0,1 & 0,1 \\
\hline \multirow{3}{*}{2005} & PŠ & 1514,8 & 156,5 & 294,3 & 143,7 & 201,2 & 161,1 & 128,4 & 70 \\
\hline & \begin{tabular}{|l|l} 
Tempo prírastku \% \\
\end{tabular} & $-4,2$ & 12,3 & 9,4 & 7,2 & 18 & $-60,7$ & 27,4 & $-13,7$ \\
\hline & \begin{tabular}{|l} 
Pomer \\
(kraj / najlepší kraj)
\end{tabular} & 1 & 0,1 & 0,2 & 0,1 & 0,1 & 0,1 & 0,1 & 0 \\
\hline \multirow{3}{*}{2006} & PŠ & 1676,9 & 156,6 & 344,1 & 146,1 & 504,3 & 153,3 & 129 & 74,5 \\
\hline & Tempo prírastku \% & 10,7 & 0,1 & 16,9 & 1,7 & 150,6 & $-4,8$ & 0,5 & 6,4 \\
\hline & $\begin{array}{l}\text { Pomer } \\
\text { (kraj / najlepší kraj) }\end{array}$ & 1 & 0,1 & 0,2 & 0,1 & 0,3 & 0,1 & 0,1 & 0 \\
\hline \multirow{3}{*}{2007} & PŠ & 1813,6 & 167,3 & 385,9 & 129,2 & 259,4 & 274,9 & 119,4 & 112,7 \\
\hline & Tempo prírastku \% & 8,2 & 6,8 & 12,1 & $-11,6$ & $-48,6$ & 79,3 & $-7,4$ & 51,3 \\
\hline & $\begin{array}{l}\text { Pomer } \\
\text { (kraj / najlepší kraj) }\end{array}$ & 1 & 0,1 & 0,2 & 0,1 & 0,1 & 0,2 & 0,1 & 0,1 \\
\hline \multirow{3}{*}{2008} & PŠ & 2064,6 & 177,3 & 392,3 & 151,7 & 268,4 & 285,9 & 166,4 & 135,8 \\
\hline & Tempo prírastku \% & 13,8 & 6 & 1,7 & 17,4 & 3,5 & 4 & 39,4 & 20,5 \\
\hline & $\begin{array}{l}\text { Pomer } \\
\text { (kraj / najlepší kraj) }\end{array}$ & 1 & 0,1 & 0,2 & 0,1 & 0,1 & 0,1 & 0,1 & 0,1 \\
\hline \multirow{3}{*}{2009} & PŠ & $22,72,5$ & 193,9 & 272,9 & 153,3 & 276,2 & 278,4 & 212,4 & 130,3 \\
\hline & Tempo prírastku \% & 10,1 & 9,4 & $-4,7$ & 1,1 & 2,9 & $-2,6$ & 27,6 & $-4,1$ \\
\hline & $\begin{array}{l}\text { Pomer } \\
\text { (kraj / najlepší kraj) }\end{array}$ & 1 & 0,1 & 0,2 & 0,1 & 0,1 & 0,1 & 0,1 & 0,1 \\
\hline \multirow{4}{*}{2010} & PŠ & 2440,6 & 250,6 & 355,6 & 156,3 & 256,4 & 273 & 221,4 & 131,1 \\
\hline & Tempo prírastku \% & 7,4 & 29,2 & $-4,9$ & 2 & $-7,2$ & $-1,9$ & 4,2 & 0,6 \\
\hline & $\begin{array}{l}\text { Pomer } \\
\text { (kraj / najlepší kraj) }\end{array}$ & 1 & 0,1 & 0,1 & 0,1 & 0,1 & 0,1 & 0,1 & 0,1 \\
\hline & $\begin{array}{l}\text { Tempo prírastku \% } \\
\text { (za } 10 \text { rokov) }\end{array}$ & 202,2 & 101,6 & 105,1 & 36,4 & 88,5 & 153 & 169,7 & 94,2 \\
\hline
\end{tabular}

Vysvetlivky: PŚ - plošný štandard; BA - Bratislavský kraj, TT - Trnavský kraj, TN - Trenčiansky kraj, NR Nitriansky kraj, ZA - Žilinský kraj, BB - Banskobystrický kraj, PO - Prešovský kraj, KE - Košický kraj Zdroj: ŠÚ SR, vlastné spracovanie 
Ukazovatel' využitel'nost' predanej plochy vyjadruje objem tržieb pripadajúcich na $\mathrm{m}^{2}$ predajnej plochy príslušného kraja a čím je ukazovatel' vyšší tým je využitel'nost' predajnej plochy lepšia a efektívnejšia. $Z$ analýzy ukazovatel'a využitel'nost' predajnej plochy (tabul'ka č.3) je zrejmé, že v tomto meradle mal najlepšiu východiskovú pozíciu na začiatku sledovaného obdobia Banskobystrický kraj, v ktorom produktivita metra štvorcového bola viac než 5200 eur. Po prvom roku zaznamenávajú rast len tri kraje a to Trnavský $(9,71 \%)$, Trenčiansky (1,41 \%) a Košický (19,57 \%). Ostatné jednotky zaznamenávajú prepad, ktorý je najvýraznejší pri Prešovskom kraji (21,1 \%). V roku 2003 vykazuje najlepšie výsledky Prešovský kraj s rastom 34,72 \%.

Tabul'ka 3: Využitel'nost' predajnej plochy za jednotlivé kraje Slovenska

\begin{tabular}{|c|c|c|c|c|c|c|c|c|c|}
\hline ROK / KRAJ & & BA & TT & $\mathbf{T N}$ & NR & $\mathbf{Z A}$ & BB & PO & $\mathbf{K E}$ \\
\hline \multirow[b]{2}{*}{2001} & VPP & 4816,9 & 3903,3 & 3423,5 & 3951,5 & 3904,9 & 5220,3 & 3762,5 & 3673,3 \\
\hline & $\begin{array}{l}\text { Pomer } \\
\text { (kraj / najlepší kraj) }\end{array}$ & 0,9 & 0,7 & 0,7 & 0,8 & 0,7 & 1 & 0,8 & 0,8 \\
\hline \multirow{2}{*}{2002} & VPP & 4298 & 4282,4 & 3471,8 & 3866,5 & 3878,9 & 5125,8 & 2968,8 & 4392,3 \\
\hline & Tempo prírastku \% & $-10,77$ & 9,71 & 1,41 & $-2,15$ & $-0,67$ & $-1,81$ & $-21,1$ & 19,57 \\
\hline \multirow{2}{*}{2003} & VPP & 4609,5 & 4030,6 & 3543,2 & 4136,6 & 3875 & 5120,4 & 3999,7 & 3914,3 \\
\hline & Tempo prírastku \% & 7,25 & $-5,88$ & 2,06 & 6,99 & $-0,01$ & $-0,11$ & 34,72 & $-10,88$ \\
\hline \multirow{2}{*}{2004} & VPP & 4838,2 & 4095,8 & 2776,8 & 3777,5 & 3586,4 & 1403,2 & 3845,4 & 3838,3 \\
\hline & Tempo prírastku \% & 4,96 & 1,62 & $-21,63$ & $-8,68$ & $-7,45$ & $-72,6$ & $-3,86$ & $-1,94$ \\
\hline \multirow{2}{*}{2005} & VPP & 5641,5 & 3493 & 3347,1 & 2728 & 3261 & 3569,7 & 3361,2 & 3998,4 \\
\hline & Tempo prírastku \% & 16,6 & $-14,72$ & 20,54 & $-27,78$ & $-9,07$ & 154,4 & $-12,59$ & 4,17 \\
\hline \multirow{2}{*}{2006} & VPP & $60,54,5$ & 3992,4 & 3590,5 & 3589,9 & 1453,5 & 4478,9 & 3741,9 & 3952,6 \\
\hline & Tempo prírastku \% & 7,32 & 14,3 & 7,27 & 31,59 & $-55,43$ & 25,47 & 11,33 & $-1,15$ \\
\hline \multirow{2}{*}{2007} & VPP & 6199,4 & 4105,5 & 3442,2 & 4458,4 & 3233,4 & 3367,2 & 4517 & 4015,3 \\
\hline & Tempo prírastku \% & 2,39 & 2,83 & $-4,13$ & 24,19 & 122,46 & $-24,82$ & 20,71 & 1,59 \\
\hline \multirow{2}{*}{2008} & VPP & 5862,9 & 4742,5 & 4109,6 & 4528,9 & 3626,7 & 3022,5 & 4599,8 & 5138,3 \\
\hline & Tempo prírastku \% & $-5,43$ & 15,52 & 19,39 & 1,58 & 12,16 & $-10,24$ & 1,83 & 27,97 \\
\hline \multirow{2}{*}{2009} & VPP & 4635,2 & 3892,8 & 4164,1 & 3773,2 & 3331,3 & 2762 & 3333 & 5192,7 \\
\hline & Tempo prírastku \% & $-20,94$ & $-17,92$ & 1,33 & $-16,69$ & 8,15 & $-8,62$ & $-27,54$ & 1,06 \\
\hline \multirow{4}{*}{2010} & VPP & 4790 & 3360,7 & 4496,9 & 4074,8 & 3411,4 & 3134,8 & 3420,5 & 4105,4 \\
\hline & Tempo prírastku \% & 3,36 & $-13,67$ & 7,99 & 7,99 & 2,4 & 13,5 & 2,63 & $-20,94$ \\
\hline & $\begin{array}{l}\text { Pomer } \\
\text { (kraj / najlepší kraj) }\end{array}$ & 1 & 0,7 & 0,94 & 0,85 & 0,71 & 0,65 & 0,71 & 0,86 \\
\hline & $\begin{array}{l}\text { Tempo prírastku \% (za } \\
10 \text { rokov) }\end{array}$ & $-0,54$ & $-13,9$ & 31,35 & 3,12 & $-12,64$ & $-39,95$ & $-9,09$ & 11,76 \\
\hline
\end{tabular}

Vysvetlivky: VPP - využitel'nost' predajnej plochy; BA - Bratislavský kraj, TT - Trnavský kraj, TN-Trenčiansky kraj, NR - Nitriansky kraj, ZA - Žilinský kraj, BB - Banskobystrický kraj, PO - Prešovský kraj, KE - Košický kraj

Zdroj: ŠÚ SR, vlastné spracovanie

V roku 2004 pozorujeme pokles u 6 z 8 pozorovaných krajov, pričom najviac viditel'ný je v Banskobystrickom kraji až $72,6 \%$, čo posúva tento kraj hlboko pod úroveň hranice produkčných možností, no po roku sledujeme nárast v danom kraji viac ako o 154 \%, čo ho približuje opät' $\mathrm{k}$ strednej hodnote produkcie na $\mathrm{m}^{2}$. V zvyšnej časti pozorovanej periódy zaznamenávame výraznejšie zmeny už len pri Žilinskom kraji (prepad o 55,43 \% v roku 2006 a rast o 122,46 \% v roku 2007). Pri analýze daného ukazovatel'a je možné vidiet' aj to, že počas sledovaného obdobia vykazovali efektívne využívanie predajnej plochy len dva kraje Banskobystrický kraj (prvé 3 roky) a Bratislavský kraj (zvyšných 7 rokov). Porovnávaním 
relatívnych zmien si môžeme všimnút' aj to, že ani jedna územná jednotka si nedokázala udržat' pravidelné ročné prírastky a celá perióda je sprevádzaná kolísaním. Najvýraznejšiu regresiu zaznamenal Banskobystrický kraj (39,95 \%), ktorý sa z najlepšieho využívania predajných plôch prepadol až na úplné dno v tomto meradle. Na druhej strane najvýraznejší progres zaznamenal Trenčiansky kraj (31,35 \%). Z analýzy ukazovatel'a využitel'nost' predajnej plochy sa dá konštatovat' kolísavý vývoj v sledovaných krajoch, k čomu výrazne prispievajú aj regionálne zmeny nákupného správania spotrebitel'ov v dôsledku rozdielnej kúpyschopnosti a straty zamestnania.

Z analýzy indexu lokalizácie (tabul'ka č.4), ktorý meria pomer zastúpenia sledovaného odvetvia v regióne k počtu obyvatel'ov, je možné vidiet', že na začiatku meranej dekády ani jeden z krajov nemal podl'a hodnôt indexu lokalizácie (d'alej len IL) proporcionálne zastúpené odvetvie maloobchodu voči regionálnemu počtu obyvatel'stva.

Tabul'ka 4: Index lokalizácie maloobchodu za jednotlivé kraje Slovenska

\begin{tabular}{|c|c|c|c|c|c|c|c|c|c|}
\hline \multicolumn{2}{|c|}{ ROK / KRAJ } & BA & TT & TN & NR & ZA & BB & PO & KE \\
\hline \multirow{3}{*}{2001} & Počet zamestnaných & 17256 & 2621 & 4295 & 2986 & 4374 & 4071 & 2950 & 2353 \\
\hline & Počet obyvatel'ov & 599042 & 550918 & 604917 & 712312 & 692434 & 661343 & 791335 & 766650 \\
\hline & IL & 3,79 & 0,63 & 0,93 & 0,55 & 0,83 & 0,81 & 0,49 & 0,4 \\
\hline \multirow{3}{*}{2002} & Počet zamestnaných & 20482 & 2980 & 4673 & 3404 & 4507 & 4315 & 3297 & 2283 \\
\hline & Počet obyvatel'ov & 599736 & 550911 & 603494 & 711002 & 693041 & 660110 & 793182 & 767685 \\
\hline & IL & 4 & 0,63 & 0,91 & 0,56 & 0,76 & 0,77 & 0,49 & 0,35 \\
\hline \multirow{3}{*}{2003} & Počet zamestnaných & 21065 & 3134 & 4550 & 3567 & 4437 & 4534 & 3281 & 2248 \\
\hline & Počet obyvatel'ov & 599787 & 552014 & 602166 & 709752 & 693499 & 658953 & 794814 & 769068 \\
\hline & IL & 4,04 & 0,65 & 0,87 & 0,58 & 0,74 & 0,79 & 0,47 & 0,34 \\
\hline \multirow{3}{*}{2004} & Počet zamestnaných & 23027 & 3184 & 4384 & 3452 & 4453 & 4128 & 3340 & 2321 \\
\hline & Počet obyvatel'ov & 601132 & 553198 & 601392 & 709350 & 694129 & 658368 & 796745 & 707508 \\
\hline & IL & 4,27 & 0,64 & 0,81 & 0,54 & 0,72 & 0,7 & 0,47 & 0,37 \\
\hline \multirow{3}{*}{2005} & Počet zamestnaných & 24567 & 3095 & 4842 & 3532 & 4992 & 4708 & 3366 & 1992 \\
\hline & Počet obyvatel'ov & 603699 & 554172 & 600386 & 708498 & 694763 & 657119 & 798596 & 771947 \\
\hline & IL & 4,29 & 0,59 & 0,85 & 0,53 & 0,76 & 0,76 & 0,44 & 0,27 \\
\hline \multirow{3}{*}{2006} & Počet zamestnaných & 26737 & 3282 & 4276 & 3642 & 5385 & 5261 & 3381 & 1985 \\
\hline & Počet obyvatel'ov & 606753 & 555075 & 599847 & 707305 & 695326 & 655762 & 800483 & 773086 \\
\hline & IL & 4,41 & 0,59 & 0,71 & 0,51 & 0,77 & 0,8 & 0,42 & 0,26 \\
\hline \multirow{3}{*}{2007} & Počet zamestnaných & 27648 & 3516 & 5803 & 3639 & 5989 & 5403 & 3726 & 2514 \\
\hline & Počet obyvatel'ov & 610850 & 557151 & 599831 & 706758 & 695698 & 654668 & 801939 & 774103 \\
\hline & IL & 4,2 & 0,59 & 0,9 & 0,48 & 0,8 & 0,77 & 0,43 & 0,3 \\
\hline \multirow{3}{*}{2008} & Počet zamestnaných & 29768 & 3853 & 5405 & 3529 & 6427 & 5882 & 4440 & 3335 \\
\hline & Počet obyvatel'ov & 616578 & 559934 & 599859 & 706375 & 696347 & 653697 & 803955 & 775509 \\
\hline & IL & 4,17 & 0,59 & 0,78 & 0,43 & 0,8 & 0,78 & 0,48 & 0,37 \\
\hline \multirow{3}{*}{2009} & Počet zamestnaných & 31104 & 4137 & 5135 & 3721 & 6197 & 6108 & 4855 & 3037 \\
\hline & Počet obyvatel'ov & 622706 & 561525 & 599214 & 705661 & 697502 & 653186 & 807011 & 778120 \\
\hline & IL & 4,21 & 0,62 & 0,72 & 0,44 & 0,75 & 0,79 & 0,51 & 0,33 \\
\hline \multirow{3}{*}{2010} & Počet zamestnaných & 32280 & 4393 & 4865 & 3769 & 5817 & 6004 & 4660 & 3270 \\
\hline & Počet obyvatel'ov & 628686 & 563081 & 598819 & 704752 & 698274 & 652218 & 809443 & 780000 \\
\hline & IL & 4,29 & 0,65 & 0,68 & 0,45 & 0,7 & 0,77 & 0,48 & 0,35 \\
\hline
\end{tabular}

Vysvetlivky: IL - index lokalizácie; BA - Bratislavský kraj, TT - Trnavský kraj, TN - Trenčiansky kraj, NR Nitriansky kraj, ZA - Žilinský kraj, BB - Banskobystrický kraj, PO - Prešovský kraj, KE - Košický kraj Zdroj: ŠÚ SR, vlastné spracovanie 
Hodnoty pre Bratislavský kraj v roku 2001 ukazujú nadproporcionálne zastúpenie (IL > 1; index lokalizácie dosahoval hodnotu až 3,79). Vo všetkých ostatných krajoch index lokalizácie dosahoval nižšiu hodnotu ako 1, čo znamenalo, že odvetvie maloobchodu je $\mathrm{k}$ počtu obyvatel'ov zastúpené podproporcionálne. Vidíme, že najbližšie bol k proporciálnemu stavu Trenčiansky kraj, s hodnotou 0,93, Žilinský kraj $(0,83)$ a Banskobystrický kraj $(0,81)$. V nasledujúcom roku zaznamenal najvýraznejší nárast Bratislavský kraj, čím len potvrdil svoju dominanciu. Ostatné územné jednotky nezaznamenali výchylky väčšie než jednu desatinu vzhl'adom na hodnoty namerané v predchádzajúcom roku. V roku 2003 sa Bratislavský kraj posunul na hodnotu 4,04, zatial' čo všetky ostatné kraje sa dostali pod hodnotu 0,9. V danom období je možné pozorovat' divergenciu v hodnotách indexu lokalizácie ostatných krajov od hodnôt najlepšieho kraja. V roku 2006 sa daná divergencia prehĺbila, čo sa prejavilo v tom, že ostatné kraje nedosahovali ani hodnotu indexu lokalizácie 0,8, zatial' čo Bratislavský kraj sa posunul až na hodnotu 4,41. V roku 2007 Trenčiansky kraj narástol na hodnotu $(0,9)$, avšak táto zmena sa ukázala iba ako malý a dočasný výkyv, ked’že v nasledujúcom roku zaznamenal opät' pád na hodnotu $(0,78)$. V roku 2009 už ani jeden zo zvyšných 7 krajov neprekročil hranicu $(0,8)$, čo platí aj pre rok 2010. Z vývoja hodnôt tohto ukazovatel'a je d’alej možné usúdit', že na Slovensku máme jeden kraj (Bratislavský kraj) s vysoko nadproporcionálnym zastúpením maloobchodnej siete a 7 krajov s podproporciálnym zastúpením maloobchodnej siete v regióne. Počas celého sledovaného obdobia je možné sledovat' prehlbovanie rozdielov medzi Bratislavským krajom a ostatnými krajmi Slovenskej republiky v oblasti priestorového usporiadania maloobchodnej siete.

\section{Záver}

Nakupovanie predstavuje $v$ dnešnej spoločnosti jednu zo základných a najobvyklejších foriem sociálneho jednania. Ak by sme sledovali vzt’ah nakupovania a miesta nákupu, zistili by sme, že nie vždy musia platit' ekonomické dôvody a racionálne správanie sa spotrebitel'ov.

Zhodnotenie vývoja maloobchodných sieti v regiónoch Slovenskej republiky bolo realizované na základe vybraných indikátorov koncentrácie a lokalizácie. Na základe vykonanej analýzy koncentrácie a lokalizácie maloobchodnej siete v regiónoch Slovenskej republiky je možné konštatovat', že Bratislavský kraj má v sledovanom období výraznú dominanciu. Toto dominantné postavenie Bratislavského kraja je v súlade s klasickými lokalizačnými teóriami, hlavne čo sa týka teórie centrálnych miest od W. Christallera, na ktorú nadviazal J. Friedmann s teóriou polarizačného vývoja, podl'a ktorej ekonomický rast krajiny môže byt' posilnený hierarchickým systémom miest a ich funkčnými regiónmi. Posilnením hierarchického systému miest však zákonite dochádza $\mathrm{k}$ selekcii centier rastu, čo nezaručuje dosiahnutie konvergencie. (Sloboda, 2006; Blažek, 1993; Blažek a Uhlír, 2002; Maier a Tödtling, 1998)

Zmeny v nákupnom správaní vyvolávajú hlavne nasledujúce atribúty: potreba, ponuka, efektívny kúpyschopný dopyt, možnosti dopravy a vlastnosti maloobchodných prevádzok. V súčasných podmienkach trhovej ekonomiky vstupuje do spotrebitel'ského rozhodovania celý rad d'alších činitel'ov (ekonomické, sociálne, kultúrne a návykové faktory), ktoré sa $\mathrm{v}$ jednotlivých regiónoch značne líšia. Vplyv na konečný výsledok poradia $\mathrm{v}$ jednotlivých krajoch na Slovensku v sledovaných indikátoroch má okrem čisto ekonomických dôvodov, aj špecifické správanie sa spotrebitel'ov jednotlivých regiónov a sociálna štruktúra v ekonomike, čo naznačujú aj existujúce štúdie $\mathrm{v}$ oblasti novej ekonomickej sociológie a sociálnej ekonomiky. (Hofreiter, 2011; Lubelcová, 2012)

K primeranému rozvoju spotrebitel'ského správania a maloobchodnej siete $\mathrm{v}$ jednotlivých regiónoch Slovenska by malo $\mathrm{v}$ budúcnosti prispiet' aj riešenie chudoby rómskeho 
obyvatel'stva v marginalizovaných oblastiach (Želinský, 2011) a vytváranie priaznivých podmienok pre pritiahnutie zahraničného kapitálu do zaostávajúcich regiónov vo forme priamych zahraničných investícii. (Kotulič, 2008)

Je vel'mi pravdepodobné, že pri zovšeobecnení vzt'ahov medzi nákupným správaním spotrebitel'ov a obchodnou ponukou, bude koncentrácia v oblasti služieb maloobchodu narastat', čo pre maloobchodníkov bude znamenat' stupňovanie konkurenčného boja a snaha o zmysluplnú inováciu bude otázkou budúceho smerovania a následného prežitia $\mathrm{v}$ danom odvetví.

Ďalší výskum plánujeme v budúcnosti rozšírit' aj o predajne s počtom 1-19 zamestnancov, o problematiku priemerných miezd a produktivity práce a dané výsledky následne porovnat' na nadnárodnej úrovni, s ciel'om rozšírit' poznanie $\mathrm{v}$ danej oblasti skúmania a viac objektivizovat' prezentované výsledky.

\section{Pod'akovanie}

Tento článok bol spracovaný za podpory výskumného projektu KEGA 032PU-4/2013.

\section{Literatura}

[1] BARTÁKOVÁ, G. a kol., 2007. Základy marketingu II. Bratislava: Univerzita Komenského v Bratislave. ISBN 978-80-969834-4-5.

[2] BLAŽEK, J., 1993. Regionální vývoj a regionální politika: hlavní prístupy v zemích západní Evropy. In: L. SÝKORA, ed. Teoretické př́stupy vybrané problémy v současné geografii. Praha: PrF UK Praha, s. 120-146.

[3] BLAŽEK, J. a D. UHLÍŘ, 2002. Teorie regionálního rozvoje: Nástin, kritika, klasifikace. Praha: Karolinum. ISBN 80-246-0384-5.

[4] BUČEK, M. a kol., 1992. Priestorová ekonomika. Bratislava: ES EU. ISBN 80-2250406-8.

[5] DICKEN, P., 2003. Global Shift. London: Sage Publications. ISBN 0-7619-7150-5.

[6] HOFMAN, J., J. JEŽEK, H. STARZYCZNÁ, B. BLECHOVÁ, L. JANEČKOVÁ, H. KOLIBOVÁ, P. PELLEŠOVÁ, P. TULEJA, a M. VAŠTÍKOVÁ, 2005. Exogenní a endogenní faktory regionálního rozvoje - zhodnocení empirických zkušeností a teoretických přistupů $k$ pólům rozvoje. Karviná: Slezská univerzita v Opavě. ISBN 807248-337-4.

[7] HOFREITER, R., 2011. Nová ekonomická sociológia a štruktúrny kontext trhu. Sociológia - Slovak Sociological Review, 43(5), 528-549. ISSN 0049-1225.

[8] JEŽEK, J. a kol., 2007. Budování konkurenceschopnosti měst a regionů v teorii a praxi. Plzeň: Západočeská univerzita v Plzni. ISBN 978-80-7043-632-5.

[9] KOTULIČ, R., 2008. Neoklasický model ekonomického rastu a jeho vplyv na ekonomický a sociálny rozvoj regiónu v poznatkovej ekonomike. Politické vedy, 9(1-2), 127-136. ISSN 1335-2741.

[10] KUNC, J., P. TONEV, B. FRANTÁL a Z. SZCZYRBA, 2012. Nákupní spád, nákupní chování a nákupní centra: příklad brněnské aglomerace (příspěvek ke studiu denních urbánních systémů). Sociologický časopis / Czech Sociological Review, 48(5), 879-910. ISSN 0038-0288. 
[11] LUBELCOVÁ, G., 2012. Sociálna ekonomika: koncepty, príležitosti, riziká. Sociológia - Slovak Sociological Review, 44(1), 83-108. ISSN 0049-1225.

[12] MAIER, G. a F. TÖDTLING, 1998. Regionálna a urbanistická ekonomika. Regionálny rozvoj a regionálna politika. Bratislava: ELITA. ISBN 80-8044-049-2

[13] MICHAELI, E., R. MATLOVIČ, R. IŠTOK a kol., 2009. Regionálny rozvoj pre geografov. Prešov: PU v Prešove. ISBN 978-80-555-0065-2.

[14] MITRÍKOVÁ, J., 2008. Geografické aspekty transformácie maloobchodu a nákupného správania sa na Slovensku. Prešov: PU v Prešove. ISBN 978-80-8068-922-3.

[15] SKOPAL, J., K. KRÁLIKOVÁ a J. KRÁLIK, 2008. Vývoj a současný stav globálního podnikání. In: J. JEŽEK, ed. Nadregionálna spolupráca Trnavská: Zborník príspevkov z medzinárodnej vedeckej konferencie konanej 16. - 17. októbra 2008 na Vysokej škole v Sládkovičove. Sládkovičovo: VŠS, s. 38-71. ISBN: 978-80-89267-14-9.

[16] SLACH, O., 2008. Kreativní odvětví a jejich prostorová organizace. In: J. JEŽEK, ed. Nadregionálna spolupráca Trnavská: Zborník príspevkov z medzinárodnej vedeckej konferencie konanej 16. - 17. októbra 2008 na Vysokej škole v Sládkovičove. Sládkovičovo: VŠS, s. 85-93. ISBN: 978-80-89267-14-9.

[17] SLOBODA, D., 2006. Slovensko a regionálne rozdiely: Teórie, regióny, indikátory, metódy [online]. [vid. 20. februára 2013]. Dostupné z: http://www3.ekf.tuke.sk/re/Disparity\%20a\%20perifernost/Regionalne\%20disparity/Slov ensko_a_regionalne_rozdiely.pdf

[18] SPILKOVÁ, J., 2012. Geografie maloobchodu a spotřeby. Věda o nakupování. Praha: Karolinum. ISBN 978-80-246-1951-4.

[19] ŠÚ SR (Štatistický úrad Slovenskej republiky), 2012. RegDat [online]. [vid. 19. Mája 2012]. Dostupné z: http://px-web.statistics.sk/PXWebSlovak/

[20] TEJ, J., 2007. Hodnotenie regionálneho vývoja zamestnanosti v Slovenskej republike [online]. In: V. KLÍMOVÁ, ed. X. Mezinárodní kolokvium o regionálních vědáchsborník př́spěvků z kolokvia konaného v Pavlově 20. - 22. června 2007. Brno: Masarykova univerzita, s. 37-43. [vid. 20. júna 2012]. Dostupné z: http://is.muni.cz/do/1456/soubory/katedry/kres/4884317/sbornik2007.pdf

[21] VIESTOVÁ, K., 1995. Distribúcia obchod predajňa. Bratislava: SPN. ISBN 80-0800444-4.

[22] ŽELINSKÝ, T., 2011. Mikrofinancie ako alternatívny nástroj na riešenie problému chudoby rómskeho obyvatel'stva v marginalizovaných regiónoch. Sociológia - Slovak Sociological Review, 43(1), 57-88. ISSN 0049-1225. 